\title{
AS VARIANTES ESTIGMATIZADAS EM MACUNAÍMA, DE MÁRIO DE ANDRADE
}

\section{THE STIGMATIZED VARIETIES IN MACUNAÍMA, BY MÁRIO DE ANDRADE}

\author{
Recebido: 27/03/2020 | Aprovado: 25/05/2020 | Publicado: 10/07/2020 \\ DOI: https://doi.org/10.18817/rlj.v4i1.2193
}

Priscila de Sousa Lima ${ }^{1}$

Orcid ID: https://orcid.org/0000-0001-5905-3893

Lígia Vanessa Penha Oliveira²

Orcid ID: https://orcid.org/0000-0001-6771-9384

\begin{abstract}
Resumo: Em uma época de constantes mudanças, inclusive de tradições intelectuais, Macunaíma remontava a visão de homem, de herói e de língua no período modernista, promovendo uma ruptura do tradicionalismo nas manifestações da inteligência artística brasileira. Ao buscar liberdade de expressão e criação, a obra, que versa sobre a realidade nacional e valorização da cultura popular, precipuamente da fala popular, reconstrói significados e instiga revisões autocríticas sobre a língua genuinamente brasileira. Neste artigo, busca-se evidenciar a visão de língua proposta pelos autores modernos, principalmente Mário de Andrade. À vista disso, os postulados da Sociolinguística são empregados para analisar as representações dos fenômenos linguísticos estigmatizados destacados na obra, ao elucidar o uso recorrente de termos da variedade não padrão, explicando como cada fenômeno linguístico ocorre e o quanto esses processos estão correlatos à atualidade.
\end{abstract}

Palavras-chave: Macunaíma. Sociolinguística. Variedade não padrão. Variedade padrão.

Abstract: In a time of constant change, even of intellectual traditions, Macunaíma traced the ideas of man, hero and language in the modern period, promoting a break with traditionalism in Brazilian artistic intelligence manifestations. In seeking freedom of artistic expression and creativity, the novel, which addresses the reality and the appreciation for popular culture in Brazil, primarily from the language of the people, reconstructs meanings and instigates self-critical reviews of the genuinely Brazilian language. In this article, we seek to highlight the language perspective proposed by modern authors, especially Mário de Andrade. Therefore, Sociolinguistic theory is applied to analyze the representations of the stigmatized linguistic phenomena that are highlighted in the novel; we elucidate the recurrent use of terms from the non-standard dialect, explaining how each linguistic phenomenon occurs and how closely these processes are related to the present.

Keywords: Macunaíma; Sociolinguistics; Non-standard dialect; Standard dialect.

1 Pós-graduanda em Ensino de Língua Portuguesa/UEMA, Especialista em Engenharia de Software/Universidade Estácio de Sá - Campus Teresina/Piauí. Graduada em Tecnóloga em Análise e Desenvolvimento de Sistemas/Centro Universitário de Ciências e Tecnologia do Maranhão UniFacema. Graduada em Letras, Língua Portuguesa e Literaturas de Língua Portuguesa/ Universidade Estadual do Maranhão - UEMA. Integrante do grupo de pesquisas em Literatura, Arte e Mídias - LAMID (UEMA). E-mail: priscilasousa73@gmail.com

${ }^{2}$ Mestre em Letras/UESPI. Especialista em Ensino de Língua Portuguesa e Língua Inglesa/IESF, Graduada em Letras Português/ Inglês e Respectivas Literaturas/UEMA. Professora seletivada na Universidade Estadual do Maranhão, atuando nos cursos de Pedagogia e de Letras. Integrante do grupo de pesquisas em Literatura, Arte e Mídias - LAMID (UEMA). E-mail: Ivpoliveira@hotmail.com 


\section{Introdução}

Em vários períodos da colonização, o Brasil teve acesso a diferentes culturas e costumes trazidos pelos imigrantes, o que possibilitou também o contato com outras línguas, além disso, "as variedades linguísticas estigmatizadas constituem a imensa maioria da nossa população, secularmente negligenciada [...] no que diz respeito à educação formal" (BORTONI-RICARDO, 2004, p. 07), o que atualmente repercute em uma grande diversidade linguística. Partindo-se do princípio de que a língua é viva e está sempre se modificando, é perceptível que essas mudanças não se referem somente à intervenção de outros povos, mas a vários outros aspectos como: neologismos, gírias e a tecnologia que influencia a linguagem, principalmente na internet.

Nesse sentido, a língua e a sociedade estão interligadas, pois cada falante utiliza a língua para expressar suas ideias e imprimir marcas por meio das novas situações com as quais se depara no meio social. Recorre-se, portanto, para estudar os fenômenos linguísticos, à Sociolinguística, que tem por objeto de estudo as diversidades linguísticas presentes nos mais variados níveis da linguagem, como aponta Mollica, "esta ciência se faz num espaço interdisciplinar na fronteira entre língua e sociedade [...] e [...] considera - em especial - como objeto de estudo, a variação" (2007, p. 9).

A Sociolinguística tem sido uma das áreas da Linguística mais investigadas nos últimos tempos, resultando na análise das descrições da língua, em questões educacionais e sociais que abrangem estudos relativos à língua/sociedade. William Labov, linguista norte-americano, em 1960, anos de luta pela igualdade racial nos Estados Unidos, contestava as afirmações de que os negros eram inferiores aos brancos porque eram "cultural e linguisticamente privados". Labov mostrou por meio de suas pesquisas uma visão diferente daquela que se tinha na época. Em seus estudos, passou a descrever a heterogeneidade linguística porque para ele todo fato linguístico relaciona-se a um fato social, e a língua sofre implicações de ordem fisiológica e psicológica.

É necessário mostrar que, assim como na sociedade, a língua também sofre variações, até mesmo nas camadas mais privilegiadas dos falantes urbanos, 
e que a discriminação social se torna discriminação linguística. Desse modo, é pertinente a observação feita adiante:

\begin{abstract}
Pelo que se pode concluir, toda a questão linguística vai além de constituir um simples rol de palavras e regras; é, portanto, mais que um inventário de erros e acertos. É algo que entra pelo terreno social, do cultural, do político, do simbólico, de suas representações de valores. Não pode, pois, engessar-se na imobilidade de um tempo, de um grupo, de uma classe (ANTUNES, 2007, p. 91).
\end{abstract}

Depreende-se, então, que os fenômenos ocorridos na língua, no caso a portuguesa, não são aleatórios e possuem, conforme Compagnon (2009), uma explicação quer seja por meio de uma visão diacrônica (desenvolvimento histórico observando as mudanças estruturais da língua), ou sincrônica (descrição da língua tal como existe em dada época).

Desse modo, procurou-se aprofundar as noções que se têm a respeito da língua e de sua estrutura, nas observações dos elementos linguísticos em Macunaíma, de Mário de Andrade. Assim, o trabalho de análise das variantes estigmatizadas na obra citada propõe argumentar que falar uma variedade diferente da norma-padrão não é falar errado ou de forma incorreta e incoerente, e sim usar uma manifestação linguística que possui uma explicação científica.

\title{
Norma não padrão e norma padrão
}

Sabe-se que a língua portuguesa e as línguas em geral não dispõem de restrições, ou seja, não estão fechadas em si mesmas como se fossem um sistema homogêneo. Dessarte, como defende Bechara (2009), a língua seria um produto histórico e, ao mesmo tempo, uma unidade idealizada, devido à impossibilidade de alcançar, na realidade, uma língua que se quer homogênea, unitária. Desse modo, apresenta grande diversidade em seus grupos e comunidades de fala por possuir um dinamismo que lhe é característico.

Desde que nascemos, somos rodeados por signos linguísticos, que se tornam reais a partir do momento em que é possível, quer seja por associação ou imitação, a formulação de mensagens. Nesse processo, a língua desempenha papel fundamental, pois é o meio de comunicação usado por seus falantes nos mais diferentes níveis de interação com o qual estes se deparam; ela proporciona 
ao usuário expressar suas concepções, ideias, atribuir significados, fazer críticas.

Pensar a língua como algo uniforme é um mito e um grande equívoco. E sobre essa questão Bagno reitera que:

\begin{abstract}
Esse mito é muito prejudicial à educação porque, ao não reconhecer a verdadeira diversidade do português falado no Brasil, a escola tenta impor sua norma linguística como se ela fosse, de fato, a língua comum a todos os 160 milhões de brasileiros, independentemente de sua idade, de sua origem geográfica, de sua situação socioeconômica, de seu grau de escolarização, etc. (BAGNO, 2007, p. 15)
\end{abstract}

Cada grupo, dentro de sua comunidade, possui peculiaridades próprias em seu falar, percebem-se essas variedades na realização linguística dos falantes de uma mesma língua. Com isso, em qualquer sociedade pode-se observar um conjunto de variedades coexistindo e refletindo a hierarquia dos grupos sociais. Nas relações entre língua e sociedade existem variedades consideradas superiores e outras inferiores. Isso se deve ao juízo de valor atribuído pelas pessoas à determinada manifestação verbal.

Camacho (1998), ao falar a respeito das determinações das variedades linguísticas, relata a possibilidade de identificar as características sociais de um falante desconhecido com base em seu modo de falar. Dessa forma, por meio da identidade social do emissor e do receptor e das condições sociais na produção discursiva, os aspectos da variedade linguística são identificados. A variedade padrão para Alkmim (apud MUSSALIM; BENTES, 2007, p. 40) é definida da seguinte forma:

[...] é a variedade linguística socialmente mais valorizada, de reconhecido prestígio dentro de uma comunidade, cujo uso é, normalmente, requerido em situações de interação determinadas, definidas pela comunidade como próprias, em função da formalidade da situação, do assunto tratado, da relação entre os interlocutores etc.

Sendo assim, a variedade considerada padrão é aquela que representa um ideal de unidade e que, tradicionalmente, corresponde ao "melhor modo de falar" e às regras do bom uso dos grupos socialmente dominantes. No entanto, a padronização é historicamente definida, isto é, o que é padrão hoje pode se tornar não padrão amanhã, e vice-versa. Em Macunaíma, algumas palavras grifadas fazem parte desse processo histórico, logo, é incorreto falar em língua "inferior", "primitiva", tomando por base tais fatores como podemos observar nas frases: 
Macunaíma agradeceu o feito e frechou cantando pro mocambo nativo (ANDRADE, 2007, p. 25, grifo nosso).

... e nos recessos dela os famosos Cafés maiores do mundo, todos de obra de talha em jacarandá folhado a oiro (Ibid., p. 107, grifo nosso).

Vai, ela abocanhou dois vagalumes e seguiu com eles nos dentes para alumiar o caminho (Ibid., p. 166, grifo nosso).

As formas alternativas das palavras "frechou", "oiro" e "alumiar" foram bastante veiculadas em séculos passados. Na atualidade, algumas dessas formas se estendem a outras palavras que possuem um processo de formação parecido nas variedades não padrão, palavras como "grobo", "pranta", em que há esta troca do "l" pelo "r", são bastante comuns na fala de usuários do português não padrão.

Segundo Bagno (2007), a variedade não padrão da língua portuguesa é falada pela população que possui pouco poder aquisitivo e de maioria analfabeta, e, consequentemente, nesse grupo estão àquelas crianças carentes que estudam em escola pública. Por conseguinte, o português falado por essas classes desprestigiadas não pode ser visto como uma língua "errada", por usar pronúncias distintas e construções diferentes da variedade de prestígio, como por exemplo: "véio", "trabáio".

As variações linguísticas existem, conforme Antunes, não porque "as pessoas sejam ignorantes [...], existem porque as línguas são fatos sociais, situadas num tempo e espaço concretos, com funções definidas [...]" (2007, p. 104). A realidade linguística marcada pela diversidade, conforme nos referimos, já é reconhecida em alguns documentos legais da educação como a Base Nacional Comum Curricular, que no eixo de Língua Portuguesa estabelece os objetivos a serem alcançados pelos alunos dessa disciplina, nas diferentes etapas de ensino:

Conhecer algumas das variedades linguísticas do português do Brasil e suas diferenças fonológicas, prosódicas, lexicais e sintáticas, avaliando seus efeitos semânticos.

Discutir, no fenômeno da variação linguística, variedades prestigiadas e estigmatizadas e o preconceito linguístico que as cerca, questionando suas bases de maneira crítica. (BRASIL, 2016, p. 83)

Além disso, a BNCC também direciona uma competência específica em Língua Portuguesa para o público do Ensino fundamental, que determina que os alunos devem "Compreender o fenômeno da variação linguística, demonstrando 
atitude respeitosa diante de variedades linguísticas e rejeitando preconceitos linguísticos." (BRASIL, 2016, p. 87). Pode-se compreender que ocorrem padrões diversificados na língua porque existem situações sociais diferentes, pois no estudo de qualquer grupo linguístico a conclusão que se chega é justamente que existe variedade, tal questão ratifica que a língua é constituída por um conjunto de mudanças sinalizadas pelos diferentes modos de falar.

A variedade ocorre em todos os níveis da língua através de variações: variação fonético-fonológica, variação morfológica, variação sintática, variação semântica, variação lexical e variação estilístico-pragmática. A Sociolinguística trabalha, nesse sentido, um conceito de variação que possui uma heterogeneidade ordenada, ou seja, a variação é estruturada e muito bem organizada, ocorrendo de forma não aleatória.

\section{As variantes linguísticas estigmatizadas na obra Macunaíma}

As análises realizadas neste trabalho mostram as explicações que existem na língua para o uso de variedades menos prestigiadas, e mesmo que Macunaíma seja uma obra de ficção, não se pode deixar de reconhecer as mudanças que ocorreram e continuam a ocorrer na língua. Ademais, tomando como base a obra de Andrade (2007) é possível conjecturar situações linguísticas reais por meio de trechos e falas de personagens fictícios.

O autor faz alterações gráficas em algumas palavras ao longo do texto e aborda as variedades não padrão na modalidade escrita da língua, mas com marcas típicas da oralidade, no sentido de caracterizar a língua brasileira em distinção da língua portuguesa europeia. Para tal fim, destacam-se as palavras em negrito:

No mocambo si alguma cunhatã se aproximava dele pra fazer festinha, Macunaíma punha a mão nas graças dela, cunhatã se afastava. Nos machos guspia na cara (ANDRADE, 2007, p. 13, grifo nosso).

Isso Macunaíma ficava que nem um lião [...]. Quando todas as estrelas incendiadas derramavam sobre a terra um ólio calorento que ninguém suportava de tão quente, corria pelo mato uma presença de incêndio (Ibid., p. 33, grifo nosso). 
Nas frases têm-se o uso do "si", que é um pronome oblíquo átono, usado antes de preposição, salvo quando se trata da preposição com (caso em que se diz consigo), no lugar de "se", que tem função de um pronome oblíquo tônico ou de conjunção. Ambos se diferem somente na escrita. As palavras "lião"/“leão" e "ólio"/“óleo" possuem diferenças na escrita e na pronúncia, mas o sentido da palavra é o mesmo, ainda que existam sucintas modificações nelas.

O autor, ao manifestar as expressões linguísticas das personagens, faz uso de recursos que fogem ao padrão formal da língua portuguesa a partir dos "erros" que Macunaíma e outros personagens cometem. As palavras "maginou", "fastou" e "té" são possibilidades utilizadas por falantes em situações de comunicação diária, as marcas na linguagem identificam o vocabulário inerente ao homem do campo, no que tange ao uso. É possível explicar os termos através de uma alteração fonética chamada aférese, que conforme Carvalho e Nascimento (1971) se constitui de uma perda de um fonema no começo de uma palavra, caso que é demonstrado a seguir:

Macunaíma ficou muito contrariado. Maginou maginou [...] (ANDRADE, 2007, p. 23, grifo nosso).

Macunaíma fastou sarapantado mas só consegui livrar a cabeça, todo o resto do corpo se molhou (Ibid., p. 25, grifo nosso).

— Bem, té-logo bacharel, estou meio afobado... (Ibid., p. 43, grifo nosso).

Dessa forma, a aférese é uma tendência na língua que continua a ocorrer, como em "obrigado(a)" por "brigado(a)", usada comumente por falantes da língua na atualidade, inclusive presente na fala de pessoas que possuem um determinado prestígio social ou econômico. Os termos pertencentes ao português não padrão seguem o modo natural da língua, que é a sua constante atividade, o uso dessas variedades, em oposição às formas padronizadas, não compromete o entendimento da mensagem.

Além disso, é comum na língua portuguesa usos como: "onte", "garage" em vez de "ontem", "garagem", esses usos estão relacionados com o fenômeno conhecido como desnasalização das vogais postônicas. Vejamos um trecho do capítulo II, descrito como Maioridade: 
- Tu vai por aqui, menino-home, vai por aqui, passa pela frente daquele pau, quebra a mão esquerda, vira e volta [...] (ANDRADE, 2007, p. 24, grifo nosso).

No trecho acima é possível perceber que ocorre, na palavra "home", a eliminação da nasalidade da vogal que está após a sílaba tônica "ho". Essa tendência não é novidade na língua, pois era um processo muito produtivo da passagem do latim para o português, como em examem > exame, legumem > legume, volumem > volume (BAGNO, 2013, p. 13).

Além disso, nota-se que há uma simplificação da conjugação verbal em "tu vais" por "tu vai" no início da frase. Os pesquisadores, que estudam os falares regionais e não padrão, têm verificado que existe uma inclinação generalizada a reduzir as seis formas do verbo em apenas duas, sendo: eu vou, tu (você) vai, ele vai, nós (a gente) vai, vocês vai, eles vai. As marcas da oralidade trazidas na passagem de Macunaíma reiteram a funcionalidade das variantes estigmatizadas, no momento em que se deixam de lado as concordâncias redundantes na marca do plural.

Fiorin (2002) menciona algumas alterações no sistema de pronomes pessoais, antes: tu, nós, vós (este praticamente já abolido da fala dos brasileiros), e até agora: você, a gente e vocês. Isso só demonstra a elasticidade e o movimento das línguas, em especial, a portuguesa. Seguindo a perspectiva dos fenômenos linguísticos, há ainda as variantes descritas pelo rotacismo, que é a transformação do /// em /r/ nos encontros consonantais.

Macunaíma agradeceu o feito e frechou cantando pro mocambo nativo (ANDRADE, 2007, p. 25, grifo nosso).

[...] "Marvada!" que ele gemia... Então ficava muito sofrendo, muito! e invocava os deuses bons cantando cânticos de longa duração... (Ibid., p. 39 , grifo nosso).

Na história da língua portuguesa, o fonema $/ /$, como elemento do grupo consonantal, passou a /r/: obligatione > obrigação; eclesia > igreja; blandu > brando; fluxu > frouxo; clavu > cravo. Este é, portanto, um fenômeno visível na passagem do latim vulgar para o português europeu (COUTINHO, 1969). Identifica-se acima a diferença entre a palavra "flechou" (verbo flechar) e sua alternativa "frechou" 
(usada por Camões em Os Lusíadas, canto X-verso 46), assim como na palavra "malvada" por "marvada".

À vista disso, os falantes do português não padrão são coerentes ao obedecer às tendências da língua, pois reconhecem apenas os encontros consonantais com "r" seguindo as mudanças do latim para o português (plaga > praia), não existindo encontros consonantais com "l" como em "probrema" em vez de "problema". Com base nesses traços, suspeita-se que o falante tem origem rural ou baixa escolaridade, ou está muito à vontade em uma situação extremamente familiar.

Outro fenômeno fonético bem recorrente na língua é a supressão de um ou mais fonemas no final de uma palavra. A este acontecimento dá-se o nome apócope. Sobre o fato linguístico descrito tem-se o exemplo na obra Macunaíma:

A vaca mansa dá leite, a braba dá si quisé!" (ANDRADE, 2007, p. 68).

Na frase, a palavra "quisé" é uma forma típica da variante não padrão, na qual o "r" final do infinitivo não é pronunciado, como aparecem também nos termos qué (quer), sabê (saber), passa (passar). Casos como esses são considerados pela gramática normativa como vícios de prosódia, ou seja, erros de emissão no som da fala capazes de alterar a tonicidade das palavras.

O contraste à exigência da pronúncia do /r/ forte, de verbos no infinito, não cumpridas pelos falantes da variedade não padrão, ocorre não por conta do desconhecimento por parte dos usuários quanto à pronúncia "correta", mas sim pela necessidade de tecer um discurso mais contínuo, de maneira facilitada, sem tantos travamentos de sílabas, o que sugere maior habilidade de entonação.

No português padrão da língua escrita, tem-se a existência do ditongo em palavras como: "roupa", "louro", isto é, um encontro vocálico em que duas vogais são pronunciadas. No entanto, o que pesquisas têm revelado é que o que há muito tempo se escreve "ou" é pronunciado "o", tanto na língua portuguesa brasileira quanto na de Portugal, um exemplo extraído da obra Macunaíma retrata bem o aspecto abordado:

Quando eu morrer não chores,

Deixo a vida sem sodade (ANDRADE, 2007, p. 89, grifo nosso). 
As palavras que tinham ditongo "ou" em latim estavam se transformando em "paucu" > "pouco" e "lauru" > "louro" em português. Como o "a" é muito aberto e o "u" muito fechado, a pronúncia do ditongo "au" era feita através de um movimento grande da boca. Já na zona intermediária está o "o" que acabou por aproximar o timbre "au" > "ou" (CARVALHO; NASCIMENTO, 1971).

Devido à dinamicidade da língua falada, o que era escrito e pronunciado com "ou" com o tempo passou a ser pronunciado apenas "ô". Estudos mostram que em muitas regiões do Brasil a palavra "saudade" é pronunciada "sodade", na qual ocorreu o processo de assimilação, que é a tendência da língua de tornar um som mais semelhante a outro que está próximo, adquirindo propriedade fonética que ele não tinha.

Algumas pesquisas, realizadas por linguistas, sugerem que um traço característico do português não padrão é que quase não existem palavras proparoxítonas. Desse modo, palavras como: arvre (árvore), musga (música), próprias de variedades sociais e geográficas, têm processos regulares e sua explicação remete à própria história da língua. No exemplo abaixo, ocorre tal variação:

Tinha um corgo perto com um pau caído servindo de pinguela (ANDRADE, 2007, p. 162, grifo nosso).

A palha o frosfre e o goiano

Caiu n’água, se molhou (lbid., p. 164, grifo nosso).

Imaginou que era abobra e engoliu a cabaça que virou na bexiga de Padzá (Ibid., p.189, grifo nosso).

A tendência de eliminar a vogal postônica de palavras proparoxítonas, devido à aceleração do ritmo da fala, era um processo que ocorria também do latim para o português: àsinu > asno, litera > letra. Isso demonstra que a contração não é exclusividade das formas não padrão, mas um fenômeno natural das línguas, em que as vogais que se encontravam após a sílaba tônica eram pronunciadas cada vez mais fracas até desaparecerem por completo, como em "frosfo" > "fósforo", "corgo" > "córrego" e "abobra" > "abóbora".

Constata-se que as alterações gráficas nas palavras escritas na obra Macunaíma, os desvios ortográficos encontrados em substantivos, verbos e outros termos, assim como as palavras da língua não padrão, formas de menor prestígio 
e estigmatizadas, não comprometem a enunciação. É necessário parar de tentar definir regiões e comunidades que falam melhor ou pior o português, pois as variedades surgem de acordo com as necessidades de seu grupo (os que fazem uso delas).

Ao abordar a construção das orações, são perceptíveis os desvios sintáticos significativos em sentenças do texto literário, uma vez que ao inverter a sintaxe das sentenças, colocando pronomes precedendo verbos no início de frases e posicionando sujeitos posteriormente a verbos, Mário de Andrade exercitou plenamente a liberdade na escrita, permitiu que esta fosse a expressão da oralidade, com a finalidade de não perder o caráter do herói e as emoções vividas por Macunaíma e por outros personagens.

Levando em consideração que no fazer literário é pertinente certa liberdade em relação às regras, é plausível entender que existem procedimentos diferenciados quanto à expressividade do autor. Assim, o resultado do levantamento das construções sintáticas das sentenças em Macunaíma permitiu a averiguação de contrastes entre alguns episódios do livro e normas gramaticais, referentes à variante padrão da língua portuguesa, apontando para um perfil de comportamento sintático da língua brasileira que foge aos parâmetros.

Uma alternativa recorrente na língua falada e, algumas vezes, na língua escrita é o uso do pronome "ele" como objeto direto. Segundo a norma-padrão, os pronomes pessoais do caso reto ocupam sempre a posição de sujeito da oração, e cabe ao pronome oblíquo exercer a função de objeto direto da oração, complementando o verbo transitivo. Opondo-se à gramática, os exemplos extraídos dos episódios de Macunaíma, nos quais prevalecem a valorização da linguagem coloquial e sintética, apontam para a variedade em questão:

\footnotetext{
E pediu pra mãe que largasse da mandioca ralando na cevadeira e levasse ele passear no mato (ANDRADE, 2007, p. 14, grifo nosso).

Quando tudo estava pronto Macunaíma pediu pra mãe que deixasse o cachiri fermentando e levasse ele no mato passear (lbid., p. 15, grifo nosso).
}

Nas orações acima, vê-se o uso do pronome reto "ele" como objeto direto. Para os normativistas, esse uso é considerado inadequado sendo que a forma "correta" (em negrito) seria: "E pediu para a mãe que largasse da mandioca, que 
estava ralando na cevadeira, e o levasse para passear no mato", e na segunda oração: "Quando tudo estava pronto, Macunaíma pediu para a mãe que deixasse o cachiri fermentando e o levasse para passear no mato".

As formas usadas nos trechos assinalados são associadas, sem razão, às variedades linguísticas de falantes com baixa escolaridade, por isso os falantes da norma padrão tentam evitá-la, mas na linguagem cotidiana prevalece as alternativas "pra(s)"/"pro(s)" e o uso do pronome "ele" como objeto direto na fala de usuários considerados cultos, demonstrando a importância das variedades estigmatizadas.

O uso do pronome "ele" como objeto direto também existiu em textos literários arcaicos, os quais são tomados como parâmetros pelas gramáticas normativas. A assertiva de Silveira Bueno (1995) reitera essa afirmação:

\begin{abstract}
Proíbe-se, no português clássico e moderno, que se empreguem as formas retas dos pronomes pessoais em função complementar, como objeto direto, mormente não preposicionado. Tal proibição que é dogma da gramática e do ensino oficial tanto em Portugal como no Brasil, encontra numerosas exceções no português arcaico e, em nossa pátria, é de todo transgredida na língua familiar e viva da sociedade. De tal modo está entranhado tal uso em nossos hábitos linguísticos que, embora formados por escolas até superiores, exercendo carreiras liberais onde 0 exercício intelectual é contínuo, ainda assim, empregamos formas retas objetivamente. (SILVEIRA BUENO, 1995, p. 210-211)
\end{abstract}

Depreende-se que tentar impedir um uso existente há muito tempo é inútil, pois a língua é espontânea e o que não torna esse uso ainda mais evidente é o monitoramento contínuo da gramática e das escolas. As formas retas estão presentes até mesmo na fala de pessoas formadas a nível superior, ou seja, pessoas consideradas cultas, o que só confirma a objetividade dessas alternativas linguísticas.

O uso do pronome "ele" não prejudica em nada a comunicação, não torna o texto cansativo e muito menos incompreensível. Então, por que condenar um uso antigo, vivo e presente até hoje na língua? É mais uma questão de atitude, por isso alguns falantes tentam evitar usos que são reprovados pela norma-padrão. Esses aspectos são destacados no texto abaixo:

[...] os falantes nativos têm consciência de que uma forma não goza exatamente do mesmo prestígio que outra ou, ainda, de que uma das 
formas tem determinado uso, diferente do uso da outra, embora se refiram ao mesmo significado. Os diferentes usos - na fala - não são aspectos estritamente fonológicos (ou fonético), mas pragmático ou sociolinguístico (CAGLIARI, 2002, p. 50).

O pragmatismo das variantes estigmatizadas, em contraste com os postulados tradicionais, mostra as diferenças entre o que é usado e o que poucos acham que deveria ser usado, ou seja, a língua que falamos é distinta em muitos aspectos das descrições impostas pela norma-padrão. Não se negam as formas tradicionais, no entanto, é necessário um retrato mais "real" e natural da língua que de fato é empregada pelos brasileiros cultos.

Outro uso recorrente na obra é a abordagem do pronome "mim", pronome oblíquo tônico, que como já visto deve ser usado como complemento, é pertinente citar os trechos em Macunaíma em que ele é utilizado como sujeito de infinitivos:

— Meu avô, dá caça pra mim comer? (ANDRADE, 2007, p. 23)

— Minha vó, dá aipim pra mim comer? (Ibid., p. 25)

— Abra a porta pra mim entrar! (Ibid., p. 43)

Conforme as regras estabelecidas pela gramática, as ocorrências acima são consideradas incorretas, pois somente os pronomes retos funcionam como sujeito. Então, usa-se o "eu" antes de verbos no infinitivo (terminação ar, er e ir), determinando uma ação. Assim, o modo usado na língua portuguesa tradicional seria: "- Meu avô, dê-me caça para eu comer?", "- Minha vó, dê-me aipim para eu comer?" "- Abra a porta para eu entrar!".

A forma "pra" (para) + "mim" + infinitivo, segundo Bagno (2013), já está presente no discurso de muitos falantes cultos, mas encontra dificuldades para se integrar definitivamente às variedades mais cultas. $O$ autor ainda coloca hipóteses para o surgimento desse fenômeno e mostra que de duas construções perfeitamente corretas: "Isto não é trabalho para eu fazer", "Isto não é trabalho para mim", surgiu uma terceira possibilidade: "Isto não é trabalho para mim fazer, em que o sujeito do verbo assume a forma oblíqua.

O uso do pronome "mim" como sujeito de infinitivos não é registrado somente nos dias de hoje. Na obra Inocência, de Visconde de Taunay, escritor 
romântico, tal registro data de 1872, o autor expõe em uma nota de rodapé que a ocorrência é um erro comum no interior de todo Brasil, sobretudo na província de São Paulo, onde pessoas letradas utilizam o termo com frequência. Aqui, entendese que se uma palavra ou expressão aparece registrada na língua escrita é porque já vem sendo usada na língua falada há um certo tempo.

Além disso, ainda tratando do uso de pronomes, de acordo com a gramática, o pronome átono pode assumir três posições em relação ao vocábulo tônico: ênclise (colocação do pronome depois do verbo), próclise (colocação do pronome antes do verbo) e mesóclise (intercalação do pronome átono dentro do verbo). Os autores modernistas, no tratamento da colocação dos pronomes pessoais átonos (me, te, Ihe, o, a, se, nos, vos, Ihes, os, as, se), usavam praticamente todas as colocações possíveis acolhidas ou não pela norma-padrão. A gramática utiliza algumas regras e critérios para a colocação do pronome átono e umas delas é não iniciar um período com um pronome átono. À guisa de exemplo, foram retiradas de Macunaíma algumas ocorrências:

Se ergueu na jangada e com os braços oscilando por cima da pátria... (ANDRADE, 2007, p. 91)

— Me diga uma coisa: você conhece a língua do limpim-guapá? (Ibid., p. 131)

— Me esconde! (Ibid., p. 133)

$\mathrm{Na}$ contramão das regras normativas, têm-se nos casos acima exemplos de próclise, em que os pronomes "se" e "me" vem antes dos verbos "erguer", "dizer" e "esconder". Segundo a norma-padrão deve-se usar ênclise, ou seja, os pronomes "se" e "me" deveriam ser colocados da seguinte forma: "Ergueu-se na jangada e com os braços oscilando por cima da pátria...", "Diga-me uma coisa: você conhece a língua do limpim-guapá?", e "Esconda-me”.

Considerando a colocação pronominal dos usuários da língua portuguesa, há a preferência de utilizar as formas descritas nos exemplos de Macunaíma, sendo assim, é notável construções como: "Me empresta" em vez de "Empresta-me", "Ele está se sentindo mal" no lugar de "Ele está sentindo-se mal". 
$\mathrm{Na}$ fala corrente dos brasileiros é possível iniciar orações com pronomes oblíquos, são poucos os gramáticos que reconhecem essa realidade linguística. $A$ espontaneidade natural presente na linguagem e a multiplicidade das opções de usos não são descritas como alternativas igualmente válidas pelos prescritivistas, mas como prática arbitrária e inadequada. Com o propósito de observar os fatos mencionados, o filólogo e gramático brasileiro completa:

[...] estudou-se a questão dos vocábulos átonos e tônicos, e chegou-se a conclusão de que muitas das regras estabelecidas pelos puristas ou estavam erradas, ou se aplicavam em especial atenção ao falar lusitano. A Gramática, alicerçada na tradição literária, ainda não se dispôs a fazer concessões a algumas tendências do falar de brasileiros cultos, e não leva em conta as possibilidades estilísticas que os escritores conseguem extrair da colocação de pronomes átonos (BECHARA, 2009, p. 587).

As ponderações feitas por Bechara são relevantes e um avanço, levando em conta a formalidade normativa, no entanto, mostram-se ainda tímidas no universo complexo da língua portuguesa brasileira. Mais do que o reconhecimento de construções de regras ultrapassadas ou ligadas ao português de Portugal, fazse necessária a análise pormenorizada da realidade linguística do português brasileiro, um modelo de língua legítimo que lute contra as desigualdades sociais, que dê às camadas populares o direito de também se apropriarem do dialeto de prestígio; não com o objetivo de exercer domínio, mas de participação e igualdade em relação às classes mais favorecidas.

Um dos aspectos da língua que tem causado muita discussão é o uso do gerúndio, devido às construções gramaticais de orações como: "A senhora pode estar experimentando a roupa", "Eu vou estar fazendo sua transferência". Tais construções são conhecidas como "gerundismo" que, conforme os estudiosos da gramática, são usos excessivos de formas verbais desnecessárias. Assim, nos exemplos expostos acima deve-se haver um "enxugamento" das orações: "A senhora pode experimentar", "Eu vou fazer sua transferência".

O professor Pasquale Cipro Neto (2008), ao falar do uso do gerúndio, aponta o uso das sequências: "estão a brilhar", "estão a dançar", comuns na fala de portugueses, e "estão brilhando", "estão dançando" comuns na fala de brasileiros. Nota-se que, no Brasil, é preferível a forma com gerúndio (estar 
brilhando/estar dançando), enquanto em Portugal é preferível o infinitivo (estar a brilhar/estar a dançar), ainda que algumas vezes se use o gerúndio. O mesmo autor condena e, até mesmo, ridiculariza o uso das formas descritas com vários verbos auxiliares encadeados, retoma-se o exemplo: "A senhora pode estar experimentando a roupa".

Em Macunaíma, há trechos em que há sempre o uso de gerúndio no lugar do infinitivo regido pela preposição "a". Desse modo, existem nas ocorrências essa assertiva:

No outro dia a arraiada inda estava acabando de trepar nas árvores... (ANDRADE, 2007, p. 15).

Então Macunaíma contou o sucedido e principiou chorando (lbid., p. 141).

Alguns gramáticos, mais conservadores e puristas, optam pela forma "infinitivo" + preposição "a", ainda que a forma usada com gerúndio seja uma alternativa aceitável pela gramática tradicional. A construção com o "verbo auxiliar" + "gerúndio" é usada frequentemente pelos brasileiros, assim como nos exemplos extraídos de Macunaíma: "estava acabando", "principiou chorando". Ao discorrer sobre o uso do gerúndio Elia explica que:

O gerúndio é uma forma nominal muito viva na língua oral do brasileiro. Os seus empregos corretos e aqueles que os gramáticos vêm condenando (gerúndio adjetivo sem valor progressivo, gerúndio com valores novos, inclusive de oração coordenada, etc.) se multiplicam nas vozes populares, de modo que a poesia e a prosa modernista, que tanto se empenharam em se aproximar da língua viva, estão cheias dele. (ELIA, 1975, p. 95)

O texto acima, publicado em 1975, já notava a atenção dada pelos brasileiros pelo uso do gerúndio em vez do infinitivo seguido da preposição, o que mostra a distinção entre as escolhas dos falantes portugueses e dos falantes brasileiros. Mais uma vez, defende-se que é preciso analisar a língua não nos moldes de Portugal, mas observá-la nas manifestações diárias e empreender um ensino crítico da norma-padrão.

Em suma, a proposta de ter uma concepção linguística voltada para situações reais vividas pelos brasileiros, em que as expressões que fogem do 
"padrão", como as descritas, não sejam estigmatizadas sendo que são usadas até mesmo por falantes mais escolarizados, é pertinente para que as formas não prescritivas possam ser estudadas e apresentadas como variedades de uma mesma língua, e não como marcas de segregação dos falantes.

\section{Considerações finais}

O objetivo deste trabalho foi analisar as variantes estigmatizadas na obra Macunaíma, de Mário de Andrade. Assim, pôde-se descrever o uso das formas menos prestigiadas em contraste com as normas preestabelecidas e veiculadas nas gramáticas normativas. Partiu-se de aspectos linguísticos que caracterizam a obra, de sua importância no cenário cultural brasileiro, visto que na rapsódia encontram-se reunidos elementos típicos da tradição cultural do Brasil, bem como sua contribuição para o enriquecimento da literatura que descreve com destreza as variedades populares com um excelente grau estético, não se deixando intimidar pelas variedades cultas.

Foi possível verificar, a partir dos trechos de Macunaíma, que a variedade não padrão em contraponto com a variedade padrão, considerada "melhor modo de falar" e língua de prestígio, tem construções lógicas e explicações científicas de seus fenômenos, os quais possuem recursos capazes de desempenhar funções linguísticas que proporcionam interação, comunicação e expressão.

O estudo sociolinguístico contribui na perspectiva de avaliar os conceitos e julgamentos que provocam a exclusão social; e a variação trabalha para demonstrar que a língua possui um feixe de variedades, e que cada uma possui características próprias, que servem para diferenciá-la de outras. Entende-se que não se deve observar o uso da linguagem em situações comuns de interação como um sistema sem regras e caótico, pois a variação é uma característica própria das línguas naturais. Toda variedade oferece aos seus usuários meios adequados para a expressão de conceitos e ideias lógicas; assim, não se pode limitar uma variedade e favorecer outra.

Os preceitos normativos sustentam a noção de que existe erro e acabam por prejudicar os falantes de outras variedades, surge a oposição entre estigma e prestígio, em que o prestígio está relacionado com uso "correto" e que deve ser 
imitado, está mais próximo das classes elevadas por questões políticas e econômicas; em contrapartida, tem-se o estigma que, por não seguir o modelo "padrão", acaba recebendo adjetivos de "rude”, "inculto”, "grosseiro", "língua de ignorantes" entre outros.

Cabe apontar que por mais que uma variedade não siga os parâmetros da norma oficial, ela deve ser estudada e analisada e não discriminada como se fosse uma língua inferior. As ocorrências analisadas em Macunaíma correspondem a uma pequena parcela do que a obra revela quanto às variedades não padrão, o que permite muitas discussões sobre os fenômenos linguísticos e este trabalho vem contribuir como parte integrante nesse processo.

Por fim, os estudos realizados, mediante a análise da obra, que reflete as situações reais de fala, foram de fundamental importância, tendo em vista que os traços regionais aparecem em sua maioria no discurso informal do índio Macunaíma. Desse modo, as questões fonológicas/fonéticas e sintáticas, como o uso dos pronomes divergentes da norma-padrão e outros aspectos linguísticos, mostraram que as variantes estigmatizadas seguem o processo natural da língua, não estagnada e muito menos homogênea.

Nessa perspectiva, há muito o que ser feito no tocante às questões linguísticas, faz-se necessário uma maior visibilidade dos estudos sociolinguísticos nas universidades, na mídia impressa e falada para que o conhecimento possa, se não extinguir, atenuar as atitudes linguísticas cometidas por pessoas que não têm acesso às pesquisas que tratam dos problemas que envolvem língua/sociedade.

\section{Referências}

ANDRADE, Mário de. Macunaíma, o herói sem nenhum caráter. Rio de Janeiro: Agir, 2007.

ANTUNES, Irandé. Muito além da gramática: por um ensino de língua sem pedras no caminho. São Paulo: Parábola Editorial, 2007.

BAGNO, Marcos. Preconceito linguístico: o que é, como se faz. 49. ed. São Paulo: Loyola, 2007.

Paulo: Contexto, 2013.

A língua de Eulália: novela sociolinguística. 17. ed., 2ª reimpressão. São 
BECHARA, Evanildo. Moderna gramática portuguesa. 37. ed. Ver., ampl. E atual. Conforme o novo Acordo Ortográfico. Rio de Janeiro: Nova Fronteira, 2009.

BORTONI-RICARDO. Stella Maris. Educação em língua materna: a sociolinguística na sala de aula. - São Paulo: Parábola Editorial, 2004.

BRASIL. Base Nacional Comum Curricular. Brasília: MEC, 2017. Disponível em: http://basenacionalcomum.mec.gov.br/images/BNCC. Acesso em: 06 de março de 2020.

CAGLIARI, Luís Carlos. Análise fonológica: introdução à teoria e à prática com especial destaque para o modelo fonêmico. Campinas, São Paulo: Mercado das Letras, 2002.

CAMACHO, R. G. A variação linguística. In: SÃO PAULO (Estado). Subsídios à proposta curricular para o ensino de língua portuguesa no $1^{\circ}$ e $2^{\circ}$ graus. São Paulo: SE-CENP, 1988. v. 3.

CARVALHO, Dolores Garcia.; NASCIMENTO, Manoel. Gramática histórica (para o colegial e vestibulares). 7. ed. São Paulo: Ática, 1971.

CIPRO NETO, Pasquale. Professor Pasquale discute sobre o uso do gerúndio em Inculta e Bela. 2008. Disponível em: <http://www.folha.uol.com.br/>. Acesso em: 07 de Julho de 2014.

COUTINHO, Ismael de Lima. Gramática histórica. 5. ed. Rio de Janeiro: Acadêmica, 1969.

COMPAGNON, Antoine. Literatura para quê?. Trad. Laura Taddei Brandini. Belo Horizonte: UFMG, 2009.

ELIA, Sílvio. Ensaios de filologia e linguística. 2. ed. Rio de Janeiro, Grifo; Brasília, INL, 1975.

FIORIN, José Luiz (org.). Introdução à linguística. São Paulo: Contexto, 2002.

MOLLICA, Maria Cecilia; BRAGA, Maria Luiza. Introdução à sociolinguística: o tratamento da variação. São Paulo: Contexto, 2007.

MUSSALIM, F.; BENTES, Anna C. Introdução à linguística: domínios e fronteiras. São Paulo: Cortez, 2007.

SILVEIRA BUENO, Francisco da. A formação histórica da língua portuguesa. Rio de Janeiro: Acadêmica, 1995. 